\title{
Protein requirements of infants: an operational assessment
}

\author{
B Y J. C. WA TERLOW \\ Division of Clinical Sciences, London School of Hygiene and Tropical Medicine, Keppel Street, \\ London WCIE $7 H T$
}

I want to begin with a general point. In the last decade or so a controversy seems to have arisen, in relation to requirements for both protein and energy, which I consider artificial and unreal. The story goes like this. On the one side you have the conventional concept emerging from official committees, of the requirement as something that is fixed, according to age, sex, activity level, etc. On the other side you have what is claimed to be a more enlightened point of view, that requirements cannot be fixed, because human beings have a wide capacity to adjust or adapt to changes in their intakes and circumstances. I think that the controversy is artificial, because the two sides of it simply reflect different aspects of the same reality. Everyone knows that human beings can adapt to different levels of intake of energy and protein, partly through changes in body-weight, though we know very little about the acceptable limits of adaptation, and of the mechanisms involved (Waterlow, 1986, 1990). On the other hand, from the operational point of view, if the question is posed: how much food does a particular group or even individual need?, it is necessary to provide an answer that is simple enough to be usable. The position is like that of a military commander who is asked: how many men do you need to achieve this objective? He has to come up with an answer, knowing full well that there are many different ways of achieving it.

I personally feel strongly about the artificiality of what I have called, I hope not unfairly, a controversy, because in my own work I stand on both sides of it. As chairman of the committee that produced the 'blue' report on energy and protein requirements (Food and Agriculture Organization/World Health Organization/United Nations University, 1985), I am responsible, with the co-authors of the report, for a whole series of estimates that can be regarded as 'fixed', if you wish to look at it in that way.

As a nutritionist and physiologist, I have been interested in nutritional adaptation for some 20 years. This unreal controversy is harmful because it diverts attention from two sets of questions that really are different: first, the limits and mechanisms of adaptation, as I mentioned previously; second, whether the 'operational' estimates really are needed by, and are useful for, the Agencies that ask for them. That is a question for planners. If the answer to it is 'yes, there is a need for operational estimates of requirements', we come to a third and even more difficult set of questions: how should such operational values be related to what we know of the range of human adaptability? Should they represent optima, or minima, or some middle point in the range?

These questions apply as much to infants and children as to anyone else, with perhaps this difference, that the acceptable range of adaptation is probably narrower, though this is by no means certain.

When one considers that newborn babies were able to survive for several days without food or water, buried under the debris of the earthquake in Mexico City; or that marasmic infants whose weight is no more than $30 \%$ of that expected for their age can be fully restored, at least physically, one does wonder how far infants really do constitute a particularly vulnerable group. 
Table 1. Factorial calculation of the average protein requirement of infants (Food and Agriculture Organization/World Health Organization/United Nations University, 1985)

\begin{tabular}{lcc}
\hline Age (months) . . & $3-4$ & $9-12$ \\
Nitrogen & & \\
\hline Increment $(\mathrm{mg} / \mathrm{kg}$ per d) & 55 & 30 \\
Increment $\times 1.5(\mathrm{mg} / \mathrm{kg}$ per d) & 81 & 45 \\
Corrected for $70 \%$ efficiency & 116 & 641 \\
Maintenance $(\mathrm{mg} / \mathrm{kg}$ per d) & 120 & 120 \\
Total N (mg/kg per d) & 236 & 164 \\
Total N as protein (g/kg per d) & 1.47 & 1.15 \\
Average intake from breast milk (g/kg per d) & 1.49 & - \\
\hline
\end{tabular}

\section{FACTORIAL ESTIMATES OF THE NITROGEN REQUIREMENT OF INFANTS}

Coming now to our particular subject, I will begin with some remarks about the factorial calculation of the protein requirements of infants, with reference in particular to the numbers in the Food and Agriculture Organization/World Health Organization/United Nations University (1985) report (the 'Rome report'; Table 1). For Table 1 two points in time that are particularly critical, 4 months and 1 year, have been chosen.

First, we have the maintenance requirement of $120 \mathrm{mg} \mathrm{N} / \mathrm{kg}$ per $\mathrm{d}$ from milk, varying little with age. This. of course, is the minimum amount needed to cover the obligatory losses and secure $\mathrm{N}$ balance, and it represents an efficiency of utilization that was taken as $70 \%$.

These values were derived principally from one study, that of Huang et al. (1980). The balance findings reported by Fomon (1986) lead to a somewhat lower estimate of the maintenance requirement, $84 \mathrm{mg} \mathrm{N} / \mathrm{kg}$ per d, but also a lower efficiency $(62 \%)$. After 3 months of age maintenance outstrips growth as the most important component of the child's $\mathrm{N}$ requirement. The two values quoted illustrate how insecure is the basis for our estimate of it.

What is the reason for the efficiency of utilization, whatever that means, being only $70 \%$ ? Is it something to do with the quality of the protein source? For example, is it because, according to Fomon et al. (1988), even in human milk, as a result of its high content of urea, the $\mathrm{N}$ is only $83 \%$ utilized? I hope that this question will have been discussed in more detail by Jackson (1990). Or is the inefficiency due to what Millward \& Rivers (1988) call the oxidative drive, the idea that whenever amino acids are given, part of them cannot escape oxidation? This is not really an explanation, but only a description in biochemical rather than nutritional terms, but at least it opens the way to further investigations. Finally, can this efficiency be improved? The study 25 years ago on infants recovering from malnutrition (Chan \& Waterlow, 1966) suggests that it can. but to my knowledge this has never been confirmed.

\section{THE N REQUIREMENT FOR GROWTH}

Estimates of $\mathrm{N}$ accretion at different ages were derived by Fomon et al. (1982) from measurements of body water. These are the best that we have, but can we be so sure of the factor for matching $\mathrm{N}$ to water content? In the Rome report (Food and Agriculture 
Organization/World Health Organization/United Nations University, 1985) it was assumed that the efficiency of laying down $N$ for growth was the same as the efficiency of maintenance, i.e. $70 \%$. This assumption has no logic behind it, since, as I have said, we do not understand the nature of the inefficiency. There is certainly an inefficiency of synthesis, in that about $1.5 \mathrm{~g}$ protein have to be synthesized for every $1 \mathrm{~g}$ deposited (Golden et al. 1977), but the amino acids liberated by protein breakdown can be recycled to synthesis, so this will not necessarily produce an inefficiency of $\mathrm{N}$ utilization.

Finally, it is probable that a young child does not grow absolutely regularly from day-to-day, nor even from month-to-month (Harrison, 1984; Harrison \& Schmitt, 1989). Therefore, I added an extra amount to the growth requirement, to allow for catch-up growth on good days after poor growth on bad days. The question then was: how much extra should be added? It turned out that if the growth requirement was increased by $50 \%$, at 4 months the factorial estimate of average requirement coincided with the average $N$ intake from breast milk at 4 months. That is a critical age, because it is about then that exclusive breast-feeding often seems to become inadequate (Hijazi et al. 1989). I was responsible for devising this adjustment, which has received much less criticism than I had expected. It could well be regarded as a 'fiddle', even as a prostitution of the strict physiological approach. Be that as it may, if this approach is accepted, we can no longer regard factorial estimates and estimates based on intake as independent. Breast-milk intake is made to be the gold standard.

\section{AVERAGE REQUIREMENT AND SAFE LEVELS}

Immediately a difficulty arises. Traditionally, an average requirement estimated by the factorial method should be increased by $25-30 \%$ to take account of individual variability and produce a 'safe level' which will cover the needs of virtually all subjects. But it makes no sense at all to say that to be safe the observed average intake of breast milk ought to be increased. We know from common observation that the distribution of intakes of which we have taken the average seems to meet the needs of virtually all healthy breast-fed children up to the age of some 4 months. How then can the average intake be at the same time a safe level?

At the time I was unable to think this problem through, but that has now been done by Beaton \& Chery (1988). We must suppose two distribution curves, one of intakes and one of requirements (Fig. 1). The procedure of the Rome report (Food and Agriculture Organization/World Health Organization/United Nations University, 1985) puts the average requirement as equal to the average intake. This will only work if, in each individual child there is a one-to-one correspondence between intake and requirement. If the correlation is zero, then in $50 \%$ of children the intake is likely to be below the requirement. Beaton \& Chery (1988) argue that the correlation is likely to be of the order of $0 \cdot 3$. This gives rise to two possibilities: first, if the average intake is equal to the average requirement, on statistical grounds, because of the low correlation, about $30 \%$ of breast-fed infants must be getting less protein than they need. This conclusion seems to be contrary to experience. The alternative is that the average $\mathrm{N}$ requirement is substantially less than the average intake, which then in fact represents a safe level. From Beaton \& Chery's (1988) calculations, the average crude protein requirement $(N \times 6 \cdot 25)$ at 4 months would be about $1.1 \mathrm{~g} / \mathrm{kg}$ per $\mathrm{d}$, compared with an average intake of about 1.4 $\mathrm{g} / \mathrm{kg}$ per $\mathrm{d}$. It would follow that many exclusively breast-fed infants get more $\mathrm{N}$ or protein 


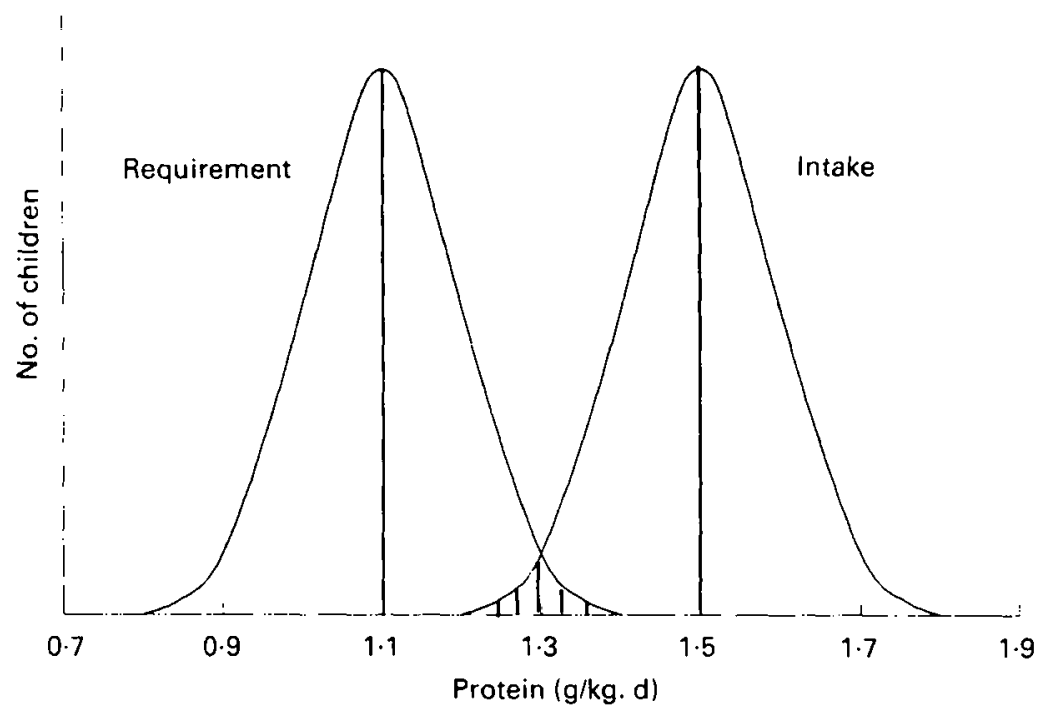

Fig. 1. Hypothetical distributions of protein intakes and requirements of breast-fed infants at 4 months. The curves are spaced in such a way that no more than $3-4 \%$ of infants have an intake less than their requirements. Correlation between intake and requirement taken as $(1.3$. Modified from Beaton \& Chery (1988).

than they actually need and that for children taken as a group the natural process of lactation provides a margin of safety. Fomon (1986), on the other hand, has argued that, since formula-fed infants gain more lean body mass than those who are breast-fed, breast-feeding is not an optimum, but a compromise which allows adequate growth of the baby without undue depletion of maternal body protein. This road, however, leads to difficult country. full of imponderables, such as 'natural' and 'optimal', and I do not propose to proceed any further along it.

Beaton \& Chery's (1988) argument cannot be controverted on statistical grounds, but it leaves a long way to go before the protein requirement of infants is securely defined. Since, as I have said, the components of the factorial estimate are not very securely based, no doubt it is possible to manipulate them so that the result agrees with Beaton \& Chery's (1988) value for average requirement, but this exercise would be as pointless as my attempt to match factorial estimates with intakes. Moreover, the numerical value of Beaton \& Chery's (1988) estimate of average requirement depends on assumptions about the coefficients of variation and their correlation. for which we have very little hard evidence.

\section{PROTEIN:ENERGY RATIOS (P:E): AN OPERATIONAL APPROACH}

All this is very unsatisfactory. I suggest that the way ahead, at least for operational purposes, must start from the solid ground of observation: that up to about 4 months of age breast milk fulfils the needs of virtually all babies for $\mathrm{N}$ and protein, provided they consume enough to satisfy their energy needs. This proviso is, of course, implicit in all estimates of protein requirements. We then come on to the practical question: what sort of food does the infant need at 6,9 or 12 months, when, on the one hand, its relative growth rate is less than at 4 months: on the other hand its absolute size has outstripped the mother's capacity to meet its energy needs? This question is posed in terms of the 
composition of food, and in attempting to answer it I am but following the course set out nearly 30 years ago by Platt \& Miller (1959) and since largely neglected, perhaps because of the unfortunate choice of the term NDp-Cals \% (nct dietary protein calories \%).

In an important later paper Payne (1975) discussed the problem of evaluating 'safe' P:E in relation to the diets of young children (see also Beaton \& Swiss, 1974, and chapter 9 of the Rome report (Food and Agriculture Organization/World Health Organization/ United Nations University, 1985)). So what is new?

The difference is that in the earlier work P:E represented in the first instance the ratio of requirements for protein and energy. these requirements being estimated in the conventional way. Difficulties arose because in order to specify a safe level for P:E, it was necessary to take account of variability in both $P$ and $E$. Once a value for safe $P$ :E had been obtained it could then be compared with the observed P:E of different diets, to determine their adequacy. My proposal is simply to start at the opposite end, with the observation that the $P: E$ of human milk appears to represent a safe level for infants in the first months of life.

If mature human milk is taken as the gold standard, its crude P:E, calculated as (total $\mathrm{N} \times 6.25 \times 4$ )/total energy, is about 7 . One cannot be more precisc, because there is some uncertainty about the most appropriate numbers to use. nor do I know of any information about the range of $P: E$ in human milk.

The first question to be considered is the effect of decreased growth rate at 1 year. Here the factorial calculation is helpful, because although the absolute values may be uncertain, the ratio of requirements at, say, 1 year to that at 4 months is not very sensitive to changes in maintenance requirement or efficiency. This ratio at 1 year may be taken as $0 \cdot 8$, so the 'safe' P:E ratio of the food comes down to $5 \cdot 8$. provided that the quality is the same as that of breast milk.

Second, there are the adjustments for digestibility and quality or net protein utilization (NPU), which have to be made when the child ceases to be exclusively breast-fed. These adjustments are relative, rather than absolute; that is the justification for calculating the $P: E$ ratio from total $N \times 6.25$. If breast milk is taken as the reference, it becomes irrelevant whether or not breast milk $\mathrm{N}$ is $100 \%$ utilized.

From the values given in the Rome report (Food and Agriculture Organization/World Health Organization/United Nations University, 1985), the digestibility of the $\mathrm{N}$ in a range of mixed diets averages about $85 \%$ of that of $N$ in milk. It is much more difficult to get reliable estimates of biological value or quality. The current debate about requirements for indispensable amino acids (Young, 1986; Millward \& Rivers, 1988) weakens my confidence in amino acid scores.

Ideally I should like to use information from balance studies on young children which fulfilled the following criteria: the diets should be examples of those typically used for young children after weaning; they should be fed at an energy level of $350-400 \mathrm{~kJ} / \mathrm{kg}$ per $\mathrm{d}$, and there should be a control study with milk. Cow's milk would be acceptable for this purpose, since in our older work we found insignificant differences from human milk (Waterlow et al. 1960). So far, to my surprise, I have not been able to identify studies which fulfil all these criteria. Those summarized by Maclean et al. (1981) come closest, but they were carried out with various staples rather than with natural mixed diets. In default of this information we might be guided by the protein values of some adult diets in the Third World which Miller \& Payne (1961) obained by rat assay (Table 2). If these rat results can be applied to young children, it appears that in many of them the net 
Table 2. Protein values of some Third World diets by rat assay (Miller \& Payne, 1961)

\begin{tabular}{llc}
\hline Country & Main Components & NDp-Cals \% \\
\hline Papua & Sago, fish & $2 \cdot 6$ \\
Gambia & Cassava, pulses & $3 \cdot 0$ \\
Jamaica & Sugar, cornmeal & $3 \cdot 2$ \\
Gambia & Cassava, fish & $4 \cdot 0$ \\
Jamaica & Maize, fish & $6 \cdot 0$ \\
Nigeria & Sorghum, pulses, fish & $7 \cdot 3$ \\
UK & Mixed & $8 \cdot 2$ \\
\hline
\end{tabular}

Breast milk (assuming 70\% efficiency) $5 \cdot 0$.

NDp-Cals \% . net dietary protein calories \%.

Table 3. Protein:energy ratios of some typical diets of 1 to 2-year-old children (not breast-fed) (Waterlow \& Rutishauser, 1974)

\begin{tabular}{|c|}
\hline Ghana \\
\hline Guatemala \\
\hline India \\
\hline Jamaica \\
\hline Polynesia \\
\hline Thailand \\
\hline Uganda \\
\hline
\end{tabular}

protein value falls well below that of breast milk. Alternatively, it might be reasonable to take an average figure of $75 \%$ for the relative quality of the protein in a typical mixed diet when fed at the usual level, compared with that of milk. Multiplying by the relative digestibility, $85 \%$, leads to a relative NPU operative of $64 \%$. This would bring the safe P:E ratio up to $9 \%(5 \cdot 8 / 0 \cdot 64)$ at 1 year. Table 3 , based on measurements of the intakes of 1 to 2-year-old children, shows that some of the diets are marginal or inadequate by the criterion derived previously, unless their quality is better than average.

Beaton \& Chery (1988) assumed that P:E in human milk was fixed. In reality probably the only food in which P:E is fixed is an industrially produced milk formula. There are so many sources of variability that I am now sceptical about whether it is possible to derive, in a way that is both rigorous and meaningful, values for a safe protein intake or a safe $P: E$ ratio. In principle this is a different argument from that based on adaptation, to which I alluded at the beginning of this talk, although of course observed variability may result from differences in the degree of adaptation.

\section{CONCLUSION}

In my view, therefore, the object of the exercise is not to establish a scientific datum-point, but the much more limited one of producing an operational tool that might be an indicator of risk. I think this is useful because contrary to much current opinion (e.g. Landman \& Jackson, 1980; Golden, 1985), I still believe that protein deficiency plays an important part in the production of kwashiorkor (Waterlow, 1984). An indicator of risk will help to concentrate enquiries on areas where the P:E of the diet is marginal or 
low by comparison with the levels proposed. It should, of course, be emphasized that except in times of famine, in no population does kwashiorkor develop in more than a very small proportion of children, who are presumably at the bottom end of the distribution of intakes in relation to their requirements.

Finally, a word about the energy component of the ratio. In past surveys of the intakes of preschool children in the Third World, it has generally been concluded that energy rather than protein is most often limiting (e.g. Waterlow \& Rutishauser, 1974). This conclusion has been based on the older estimates of energy requirements (Food and Agriculture Organization/World Health Organization. 1973; Food and Agriculture Organization/World Health Organization/United Nations University, 1985), according to which the requirement at 4 months would be about $418 \mathrm{~kJ}$ ( $100 \mathrm{kcal}) / \mathrm{kg}$ per d. More recent results, from measurements of breast-milk intake and of energy expenditure by the doubly-labelled-water method suggest that this value is substantially too high; apparently, at 4 months the energy expenditure and metabolizable energy intake of a child growing normally in a healthy environment may be as low as $293 \mathrm{~kJ}$ ( $70 \mathrm{kcal}) / \mathrm{kg}$ per d (Butte et al. 1984, 1988; Lucas et al. 1987). If these findings are generally applicable, they will reduce the extent to which energy intake is judged to be limiting. Of course, with low energy intakes absolute protein intakes will also be low. I suggest that this is a further reason why we should look again at the possibility that protein may in fact be limiting in the dicts of some Third World children.

\section{REFERENCES}

Beaton, G. H. \& Chery, A. (1988). Protcin requirements of infants: a re-examination of concepts and approaches. American Journal of Clinical Nutrition 48, 1403-1412.

Beaton, G. H. \& Swiss, L. D. (1974). Evaluation of the nutritional quality of food supplies: prediction of 'desirable' or 'safe' protein-calorie ratios. American Journal of Clinical Nutrition 27, 485.

Butte. N. F., Garza, C., O'Brian Smith, E. \& Nichols, B. L. (1984). Human milk intake and growth in cxclusively breast fed infants. Journal of Pediatrics 104, 187-195.

Butte, N. F. Wong, W. W., Lee, L. S., Garza, C. \& Klein. P. D. (1988). Encrgy expenditure of 4-month-old breast-fed and formula-fed infants. Proceedings of the Nutrition Society 47,37A.

Chan, H. \& Waterlow, J. C. (1966). The protein requirement of infants at the age of about 1 year. British Journal of Nutrition 20, 775-782.

Fomon, S. J. (1986). Protein requirements of term infants. In Energy and Protein Needs during Infancy. pp. 55-68 [S. J. Fomon and W. C. Heird, editors]. New York: Academic Press.

Fomon, S. J., Bier. D. M., Matthews, D. E., Rogers, R. R. Edwards, B. B., Ziegler, R. E. \& Nelson, S. E. (1988). Bioavailability of dietary urea nitrogen in the breastfed infant. Journal of Pediatrics 113, 515-577.

Fomon, S. J., Haschke, F., Ziegler, E. E. \& Nelson, S. E. (1982). Body composition of reference children from birth to age 10 years. American Journal of Clinical Nutrition 35, 1169-1175.

Food and Agriculture Organization/World Health Organization (1973). Energy and protein requirements. Report of a joint FAO/WHO ad hoc expert committee. Technical Report Series no. 522. Geneva: World Health Organization.

Fond and Agriculture Organization/World Health Organization/United Nations University (1985). Energy and protein requirements. WHO Technical Report Series no. 724. Geneva: World Health Organization.

Golden, M. (1985). The consequences of protein deficiency in man and its relationship to the features of kwashiorkor. In Nutritional Adaptation in Man, pp. 169-188 [K. L. Blaxter and J. C. Waterlow, editors]. London: John Libbey.

Golden, M. H. N., Waterlow, J. C. \& Picou, D. (1977). The relationship between dictary intake, weight change, nitrogen balance and protein turnover in man. American Journal of Clinical Nutrition 30. $1345-1348$.

Harrison, G. G. (1984). Application of incremental growth standards. Food \& Nutrition Bulletin 6, 18-21.

Harrison, G. A. \& Schmitt. L. H. (1989). Variability in stature growth. Annals of Human Biology 16, 4.5-51. 
Hijazi. S. S., Abulaban, A. \& Waterlow, J. C. (1989). The duration for which exclusive breast-feeding is adequate. Acta Paediatrica Scandinavica 78, 23-28.

Huang. P. C., Lin. C. P. \& Hsu. J. Y. (1980). Protein requirements of normal infants at the age of about 1 year: maintenance nitrogen requirements and obligatory nitrogen losses. Journal of Nutrition 110 , 1727-1735.

Jackson, A. A. (1990). Protcin requircments for catch-up growth. Proceedings of the Nutrition Society 49. $507-516$.

Landman, J. \& Jackson, A. A. (1980). The role of protein deficiency in the aetiology of kwashiorior. West Indian Medical Journal 29, 229-238.

Lucas, A.. Ewing, G., Roberts, S. B. \& Coward. W. A. (1987). How much energy does the breast-fed infant consume and expend? British Medical Journal 295, 75-77.

Maclean, W. C., De Romana, G. L., Placko. R. P. \& Graham. G. G. (1981). Protein quality and digestibility of sorghum in pre-school children: balance studies and plasma free amino acids. Journal of Nurrition 111 , $1928-1936$.

Miller. D. S. \& Payne. P. R. (1961). Problems in the prediction of protein values of diets. Journal of Nurition 75, 225-230.

Millward, D. J. \& Rivers. J. W. P. (1988). The nutritional role of indispensible amino acids and the metabolic hasis for their requirements. European Journal of Clinical Nurition 42. 367-394.

Payne. P. R. (1975). Safe protein-calorie ratios in diets. The relative importance of protein and energy intake as causal factors in malnutrition. American Journal of Clinical Nutrition 28, 281-286.

Platt, B. S. \& Miller, D. S. (1959). The net dietary-protein value (N.D.-p.V.) of mixtures of foods - its definition, determination and application. Proceedings of the Nutrition Societr 18, vii-viii.

Waterlow, J. C. (1984). Kwashiorkor revisited: the pathogenesis of oedema and its significance. Transactions of the Royal Society of Tropical Medicine \& Hyiene 78, 436-441.

Waterlow, J. C. (1986). Metabolic adaptation to low intakes of energy and protein. Annual Review of Nutrition 6. $495-526$.

Waterlow, J. C. (1990). Mechanisms of adaptation to low energy intakes. In Diet and Disease: Simposium of the Society for the Study of Human Biology, pp. 5-23 [G. A. Harrison and J. C. Waterlow, ecitors]. Cambridge: Camhridge University Press.

Watcrlow. J. C. \& Rutishauser, I. H. E. (1974). Malnutrition in man. In Early Malmutrition and Mental Development. Swedish Nutrition Foundation Symposium no. XII. [J. Cravioto, L. Hambraens and B. Vahlquist. editors]. Stockholm: Almqvist and Wiksell.

Waterlow, J. C.. Wills, V. G. \& Gyorgy, P. (1960). Balance studies in malnourished Jamaican infants: 2. Comparison of absorption and retention of nitrogen and phosphorous from human milk and a cow's milk mixture British Journal of Nutrition 14, 199-205.

Young, V. R. (1986). Vutritional balance studies: indicators of human requirements or of adaptive mechanisms? Journal of Nutrition 116, 70)(-70). 